\title{
Die weg van die teks na die preek. Die verkondiging van die Nuwe Testament as 'n kommunikasie- gebeurtenis*
}

\author{
AG VAN AARDE
}

What we have before us in the texts of the New Testament is almost always communication ... It follows that the exegete must do justice to the character of the document as communication. He must discern the direction in which the text he is studying is moving, retrace the path from the hearer to the speaker... Watson 1981: 11v; (kursivering deur Watson).

Bei allem muss ich mir nun aber klar sein, dass meine Predigt für die Gemeinde dieselbe Verbindlichkeit hat, die der neutestamentliche Text für jene Zeit hatte... Hier liegt die grosse Verantwortung des Predigers. Es geht um nicht weniger als darum, dass Christus in meiner Predigt und durch meine Predigt repräsentiert wird. Ich kann es nicht machen, dass es zu dieser Repräsentation kommt. Aber ich kann es erschweren oder gar verhindern. Ich verhindere es dann, ... wenn ich erkläre statt zuzusprechen; wenn ich in der Vergangenheit bleibe, statt meinen Hörern zu verkündigen ... Die wirkliche Predigtkunst besteht ... darin, dass der Pastor nicht zuerst erklärt und dann anredet ... sondern die Kunst besteht darin,

- Voordrag gelewer voor die Hervormde Teologiese Vereniging op 21 Oktober 1983 en die Praktiese Teologiese Werkgemeenskap op 17 Januarie 1984. Opgedra aan wyle prof JI de Wet, met waardering en opregte dank vir die leiding wat ek gedurende my studietydperk van hom op die gebied van die Praktiese Teologie ontvang het, en vir sy belangstelling en vriendskap. 
dass er die ganze Predigt hindurch anredet, Erklärung ... aber (als Material) in diese Anrede hineinnimmt (Marxsen 1968: 73).

Predigt ist Rede. Als Rede is Predigt aber mehr als nur des Akt des Zur-Sprache- Bringens eines Textes vor einer Zuhörerschaft. Predigt ist als Rede eine Handlung, die Teil einer Interaktion mit den Hörern ist und die eingebettet ist in einen Lebenszusammenhang mit den Hörern. Das, was der Prediger sagt, ist nur verstehbar als Reaktionen herausfordernde Anrede an Hörer und ist nur verstehbar auf dem Hintergrund einer gemeinsam geteilten Erfahrungswelt von Prediger und Hörer (Henning Luther 1983: 223).

Watson (1981:14), teen die agtergrond van die groeiende eis vir hernuwing in die prediking wat Bybels en aktueel is, sê tereg: "Many a preacher could be saved from floundering in the pulpit by stricter attention to method ..." In aansluiting by hierdie opmerking word daar in die voordrag metodologies besin oor die weg van die teks na die preek deur drie stellings te beredeneer (kyk die sitate hierbo van respektiewelik Watson, Marxsen en Henning Luther): (1) Die NuweTestamentiese geskrifte is onderskeidelik almal produkte van 'n bepaalde kommunikasie-gebeurtenis. (2) Prediking in ' $n$ reformatoriese kerk is teksgebonde en daarom behoort die verkondiging van die Nuwe Testament in 'n sekere opsig ' $n$ 'herhaling' te wees, binne 'n nuwe situasie, van die vroeëre kommunikasie-gebeurtenis tussen die (historiese) skrywer en die (historiese) leser. (3) Die weg van die teks na die preek het in 'n groot mate te doen met die verhouding tussen 'explicatio' en 'applicatio'. Aan die een kant is die aard van dié verhouding in die formele homiletiek klaarblyklik nog 'n onopgeloste probleem en aan die ander kant blyk dit dat daar in die hantering van die probleem al hoe meer aandag gegee word aan die relasionele kommunikasie-dimensie van die eksegetiese proses sowel as van die prediking.

Hierdie teoretiese besinning geskied vervolgens in vier onderafdelings: (1) die probleem met betrekking tot die verhouding 'explicatio' - 'applicatio', (2) die verhouding hermeneutiek - formele homiletiek, (3) die belang van literêre identifisering vir enersyds die metode van eksegese en andersyds die kommunikasiestrategieë van NuweTestamentiese tekste en (4) die vraag na die preekvorm. 


\section{DIE PROBLEEM MET BETREKKING TOT DIE VERHOUDING 'EXPLICATIO' - 'APPLICATIO'}

As 'n preek sou bestaan uit enersyds 'explicatio' en andersyds 'applicatio' het ons die probleem dat 'n gaping geskep word tussen die teks en die preek wat op een of ander wyse aangevul moet word. Só 'n oorbrugging doen gewoonlik òf die teks òf die gemeente geweld aan. Ernest Best bespreek sommige van hierdie illegitieme maniere waarop die teks van sy historiese en literêre binding losgemaak word en regstreeks toegepas word asof die (historiese) skrywer direk met die (hedendaagse) gemeente praat. Voorbeelde hiervan is 'vergeesteliking' (oftewel 'allegorisering') (Best 1978: 58-65), 'parallelisme' (Best 1978: 65-75), en 'n 'universalisasie' (Best 1978: 86-9). Ten opsigte van 'vergeesteliking' sê Best (1978: 59): "Allegorization becomes a temptation to those who believe that every Christian truth ought to be biblical and to be stated explicity in Scripture." Wat 'parallelisme' betref, vind ons byvoorbeeld dat daar deesdae in onder andere sogenaamde betrokke en maatskappy-kritiese prediking op so 'n manier met tekste omgegaan word asof die Bybelse leefwêreld dieselfde sou wees as dié van byvoorbeeld die 'derde wêreld'. So 'n uitlegbenadering hou dikwels nie rekening met die feit dat situasies nooit werklik dieselfde kan wees nie. 'Universalisa-

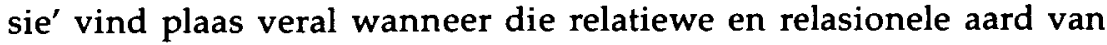
Bybelse uitsprake nie genoegsaam by Skrifgebruik in ag geneem word nie. Tekste in die Bybel het nie in 'n vakuum ontstaan nie. Met die term 'relatief' bedoel ons hier dat die Bybelskrywers tydens hulle skryfwerk nie in 'n bo-ruimtelike of bo-tydelike lugleegte, wat hulle eie tyd en situasie betref, vertoef het, asof hulle universele omstandighede in die oog sou gehad het nie. Met die term 'relasioneel' bedoel ons hier dat uitsprake van Bybelskrywers nie los te dink is van interpersoonlike verhoudinge nie.

Die aard van die weg vanaf die teks na die preek is dus die vraag: Hoe kan relatiewe, maar normgewende Bybelse uitsprake, wat as relasioneel van aard bedoel was, in nuwe situasies toegepas word? Dit is egter duidelik dat hierdie weg nie sonder meer uit twee afgebakende stadia kan bestaan waarin eers uitgelê en dan toegepas word nie.

Praktiese teoloë, soos JJ de Klerk, H Jonker en HJC Pieterse, wys wel op die probleem in verband met die tweedeling 'explicatio' - 
'applicatio', maar bied metodologies gesien nie werklik 'n oplossing nie: De Klerk (1972: $68 \mathrm{vv}$; 1979: 26) meen dat die ideaal die gelyktydige 'uitlegging' en 'toepassing' moet wees. Jonker (s a: 134-9) beveel 'n weg aan wat hy 'analities - sinteties' noem. Pieterse (1979 a: $115 \mathrm{vv}$; vgl. ook 1979 b: 6-8) voer, soos H Jonker en G Ebeling onderskeidelik, twee stappe in op die weg van die eksegese na die preek, naamlik 'meditasie' en 'translatio'. (Laasgenoemde staan ook bekend as 'woordgebeure'.) Met die konsep 'meditasie' wil hy die wisselwerking raakvat tussen die 'aktualisering' van die resultate van die eksegese en die 'vertaling' daarvan ten dienste van die prediking. Bogenoemde drie Praktiese teoloë sê egter nie hoe respektiewelik (1) 'uitleg' tegelykertyd 'toepassing' is, (2) eksegetiese gegewens sinteties georden word sodat die hele preek dwarsdeur toepassing is, en (3) 'woordgebeure' metodologies in 'n preek bewerkstellig word nie. Die aard van die pad wat daar vanaf die teks na die preek gegaan moet word, vra met ander woorde metodologiese opheldering. Vereers is dit egter noodsaaklik dat ons die verhouding hermeneutiek - formele homiletiek duideliker onder woorde bring.

\section{DIE VERHOUDING HERMENEUTIEK - FORMELE HOMILETIEK}

In die kerk is die doelstelling van die hermeneutiek van sowel OuTestamentiese as Nuwe-Testamentiese tekste die verkondiging van Jesus Christus. Die hele hermeneutiese proses geskied gelowig-biddend om die verligting van die verstand van die hermeneut en die bevestiging van sy verkondiging deur die Heilige Gees. Dit kom daarop neer dat daar ten minste twee (geloofs-) apriorieë is waarmee die hermeneut by die Bybel aankom: die vooronderstelling dat die Bybel God se Woord is en die vooronderstelling dat die Bybel in die verkondiging van die kerk as God se Woord erken en herken word. Die gebeure 'eksegese' en 'verkondiging' staan in 'n dialektiese verhouding met mekaar: "The Bible does not approach us ... like other books ... It claims from the outset to be God's word. We did not come across the Bible in the course of our cultural studies, as we came across, for example, Plato or the Bhagavad-Gita. We came to know it 
through the Christian church, which put it before us with its authoritative claim. The church's preaching, founded on the Scriptures, passes on the word of the Scriptures" (Bultman 1964: $198 \mathrm{v}$; my kursivering).

Die weg van die teks na die preek is daarom die pad wat die hermeneut as homileet moet gaan. Daar is nie ' $n$ plek op hierdie pad waar die een soos 'n aflosatleet by die ander oorneem nie. Die homileet is met ander woorde nie iemand wat maar net van die resultate van die eksegese gebruik maak nie.

Wat die aard van die verhouding 'eksegese - hermeneutiek' in hierdie verband betref, kan 'explicatio' nie sonder meer beskou word as die resultate van die eksegese en 'applicatio' as dié van die hermeneutiek nie. Hermeneutiek het met 'verstaan' te doen, maar 'verstaan' nie net in die sin van 'historiese verstaan' nie. Met die uitdrukking 'historiese verstaan' bedoel ons die gebeure dat 'n teks uit die verlede (soos die Bybel) verstaan word (vgl Ebeling 1959: 247-51). Soms word die resultate van die eksegese met die begrip 'historiese verstaan' saamgevat. Maar dan hou 'verstaan' nie noodwendig in dat die geëksegetiseerde teks gekommunikeer het nie (kyk Voster 1977: $20 \mathrm{v}$ ). Stuart 1980: $46 \mathrm{v}$ ) verwys soos volg na so 'n moontlike verkeerde opvatting: "Many exegetes believe that their responsibilities stop with the past: exegesis is the attempt to discover what the text meant, not what it means now. Placing such arbitrary limits on exegesis is unsatisfactory ... it leaves the actual personal or corporate existential interpretation and use of the passage to subjectivity ... Naturally, the exegete cannot actually control what the reader does in response to the passage. But the exegete can - and must - do his or her best to define the areas within which a faithful response will be found ..."

Indien ons in ooreenstemming met Stuart se bedoeling die begrip 'respons' met die begrip 'kommunikasie' vervang, kom sy aangehaalde opmerking daarop neer dat 'n eksegetiese proses waarin daar nie 'n kommunikasie-gebeurtenis plaasvind nie, onbevredigend is. Dié insig mag egter nie daartoe aanleiding gee dat ons, soos W Bartholomäus (bespreek deur Bolkestein 1977 a:230), enkelvoudig beweer dat 'eksegese' bloot op teksondersoek en 'kommunikasie' op prediking betrekking het nie. Eksegese as 'historiese verstaan' èn kommunikasie is albei deel van die hermeneutiese proses: "Ausle- 
gen kann man nur, was man verstanden hat. Darum bilden Verstehen und Auslegen immer einen Zirkel" (Fendt 1970: 17). Die resultate van hierdie hermeneutiese proses (= kommunikasie-gebeurtenis) wat tussen hermeneut en teks voltrek is, word in die preek aan die gemeente weer eens kommunikeerbaar gemaak. Laasgenoemde kommunikasie-gebeurtenis (dit wil sê, die prediking) is in 'n dialektiese verhouding via die hermeneut teksgebonde en gemeentegebonde. Hierdie interaksie wat plaasvind op die pad vanaf die teks na die gemeente, word soos volg deur Stuart (1980: 47 v) geformuleer: "In the application process you have three interrelated basic concerns. First, you need to know the life issues raised in the passage. These should emerge from the exegetical data. Second, you need identify which issues or concepts are transferable from the passage to the current situation. This necessitates properly integrating and harmonizing the exegetical data from the passage with theology, both biblical and dogmatic. (Thompson 1981:33 noem dit die 'Sitz im Glauben' - AG v A). Third, you need to apply these issues or concepts accurately, by understanding current life issues. This depends on your knowledge of the audience for whom you do the exegesis..."

Wat in hierdie verband baie belangrik is, is dat dié 'weg' hoegeneemd nie by die homileet as hermeneut verby kan gaan, op pad na die gemeente toe, sonder dat daar ten opsigte van die homileet 'n 'Selbsterkenntnis' teweeggebring is nie: "Der Prediger, der mit den Mitteln der Exegese und der Hermeneutik den Text zu verstehen sucht, muss auch sich selbst zu verstehen lernen; denn er selbst gehört mit seiner gesamten leiblichen, geistigen und seelischen Existenz zum Predigtgeschehen dazu" (Fendt 1970:23). In die prediking bestaan die weg van die teks na die preek daaruit dat die (relevante) hermeneutiese arbeid van die homileet (as die materiaal van die prediking) in 'n nuwe kommunikasie-gebeurtenis tussen homileet en gemeente representeer word. Ebeling (1959: 250) beskryf hierdie 'interaksie' as die "Zusammenhang zwischen Auslegung des Textes als geschehener Verkündigung und Ausfürung des Testes in geschehender Verkündigung." (My kursivering).

Prediking is met ander woorde ' $n$ interaksie tussen die hermeneut as homileet en die gemeente ingebed binne 'n bepaalde konkrete situasie oor 'n relevante Bybelse tema/saak. As 'n kommunikasiegebeurtenis is die prediking eers dan geslaagd wanneer dit bygedra 
het tot òf die verdieping òf die vervreemding van 'n gemeentelid se bepaalde 'voorverstaan' (Rudolf Bultmann)/'verwagting' (Karl Barth) van dié tema/saak en só sy verwysingsraamwerk ten opsigte van die gepredikte tema/saak òf verruim òf verander.

Wat die binding van die prediker aan die gemeente betref, is die volgende behartigenswaardige opmerking van Seung (1982: 42) van toepassing: "That our intentions are not only formed but also expressed through our shared cultural context makes our intentions and their expressions communicable and understandable to other members of our community ... The shared cultural context makes possible the interaction of the members of its community. This is why Wilhelm Dilthey called it the 'context of interaction' (Wirkungszusammenhang)." En wat die ander binding van die prediker betref, dié aan die teks, sê Seung (1982: 186): "The transposition of oneself to another historical context is possible on the intellectual plane, but impossible on the existential plane. The intellectual transposition is inseparable from the intellectual operation of reconstructing textual meaning and its original context. The existential transposition is indispensable for the existential event of experiencing the reconstructed meaning and its truth. Since the existential transposition is impossible, the only way to experience a text and its meaning is to transpose them to our own context. That is, our hermeneutic experience is existentially bound by our own context."

So gesien, is die hermeneutiek (as 'historiese verstaan' èn kommunikasie) en prediking, één proses, naamlik die 'samesmelting van kontekste' ('Horizontverschmelzung'): die samesmelting van die 'verstaanshorison' van die homileet en dié van die gemeentelid met die intensie van die teks in ' $n$ nuwe materiële vorm. Die volgende diagram ('n aanpassing van dié van Deist en Burden 1980: 50, 52) kan as 'n grafiese voorstelling van dié proses dien: 


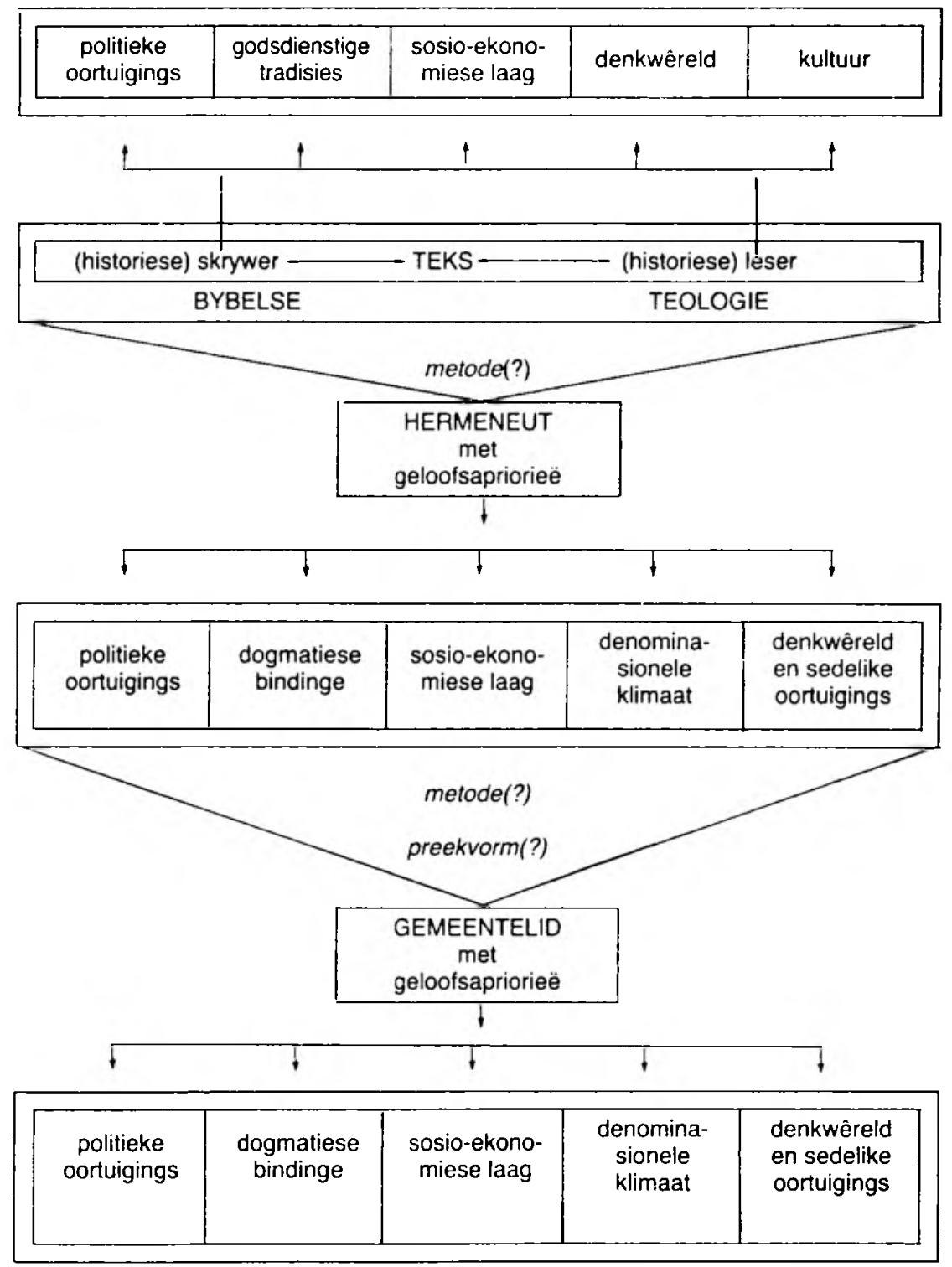

Metodologies gesien, blyk uit die bovermelde diagram dat die metode van eksegese en die strategieë waarvolgens tekste kommunikeer, sowel as die aard van preekmetodes (-vorme), kwessies is wat ten opsigte van die weg van die teks na die preek baie belangrik is. 


\section{DIE BELANG VAN LITERERE IDENTIFISERING VIR ENERSYDS DIE METODE VAN EKSEGESE EN ANDERSYDS DIE KOMMUNIKASIESTRATEGIEË VAN NUWE- TESTAMENTIESE TEKSTE}

Die poëtiek/retoriek van 'n teks is die sleutel tot 'n bepaalde metodilogiese benadering van eksegese van die betrokke teks en is van wesenlike belang vir die kommunikasie van die teks. Met die term 'poëtiek' word bedoel die wyse waarop taal in 'n diskoers georganiseer is - oftewel die wyse waarop 'n teks 'gemaak' is. Dit kom dus daarop neer dat die genre (literatuursoort) wat 'n teks verteenwoordig, verreikende implikasies het vir die wyse waarop die betrokke teks kommunikeer èn vir die wyse waarop dit geëksegetiseer behoort te word. Hierdie perspektief is ontleen aan die insigte van veral WS Vorster (1983 a). Ralph (1980: 32) skryf in dié verband: "... knowledge of genre is a benefit in hermeneutics". WD Thompson (1981), en hier te lande JJ de Klerk (1979: 22), sien ook die verband raak wat die studie van genre met eksegese sowel as prediking het. Volgens Thompson (1981: 106) vereis die onderskeie genres in die Bybel "a somewhat different approach to the exegetical, interpretive, and preaching tasks". Die soorte literatuur wat De Klerk en Thompson in die oog het, is dié wat tradisioneel in die Nuwe Testament onderskei word, naamlik evangelies, 'n historiese monografie (Handelinge van die apostels), briewe en ' $n$ apokalips. Hierdie onderverdeling is hermeneuties gesien egter nie baie bruikbaar nie. Volgens literatuurteoretici ( $\mathrm{vgl}$ o a Brooks en Warren 1970: $56 \mathrm{v}$ en Nida (1981: $29 \mathrm{v}$ ) kan taal op vyf fundamentele wyses in diskoers georganiseer word: vertelling, beskrywing, argument, dialoog, inventaris ('lists'). Hierdie diskoers-strukture kom merendeels in mengvorm voor. In die lig van 'n uitspraak soos "A study of genre is really a study of contexts" (Ralph 1980: 32), is die 'holistiese konteks' hermeneuties gesien altyd die bepalende. ' $n$ 'Geslagslys' binne ' $n$ vertelling, byvoorbeeld, sal met ander woorde as 'n element van die vertelling hanteer word. Wat die indeling van die Nuwe Testament in makro-genres betref: "As far as I am concerned there are only two types in the New Testament: those in which the material is organized in the form of narratives and those in which argument is the organizing pattern. The gospels, Acts of the apostles and Revelation are narratives, while the letters, including Hebrews, are argumentative texts" (Vorster 1983 b: 17; my kursivering). 
Vir die doeleinde van ons besinning oor die weg van die teks na die preek is die insig baie belangrik dat die wyse waarop verteltekste in die Nuwe Testament geëksegetiseer behoort te word, sowel as die kommunikasiestrategieë daarvan, van dié met betrekking tot argumentatiewe tekste verskil (kyk Anderegg 1973: 24 vv, 27 vv; Vorster 1977: 18-22).

'n Argument is ' $n$ diskoers waarin taal georganiseer is in terme van 'n reeks stellings ('gedagte-eenhede') in 'n redevoering gebaseer op aspekte soos oorsaak en gevolg, rede en resultaat, doel en resultaat, voorwaarde en resultaat, ensovoorts. Die Pauliniese redevoeringe is dikwels vanweë die diatribe-styl wat baie daarin voorkom, opgebou rondom 'n antitese-tese-gevolgtrekking tipe argumentvoering. In sulke tipe tekste vorm die tese uiteraard ' $n$ belangrike element van die skopus van die diskoers.

Die doelstelling van die eksegese is in die laaste instansie die identifisering en formulering van die skopus en die resessiewe temas van die argumentvoering (kyk Fendt 1970: 62 vv). Die 'skopus' is niks anders nie as die eintlike ding wat die skrywer wil berig; dit wil sê, dit is die dominante tema/saak in die diskoers. In party redevoeringe gebruik die skrywer 'n bepaalde 'gedagte-eenheid' (kolon) om die skopus in 'n neutedop saam te vat ('n 'summary statement'). Hierdie één kolon neem dus die sentrale posisie tussen die ander kola in die diskoers in. Al die ander kola draai om hierdie een kolon wat dan die 'wentelpunt', of beter gesê: die 'fokuspunt', van die diskoers genoem word. Die fokuspunt kan in sommige gevalle 'n kolongroep ('cluster') uitmaak. In ander diskoerse is die skopus nie op ' $n$ bepaalde punt in die gang van die redevoering, by wyse van ' $n$ enkele kolon of ' $n$ kolongroep, saamgevat nie. Dikwels sal die skrywer in die gebruik van een bepaalde woord, of woorde wat 'n semantiese eenheid vorm, die aandag op die skopus vestig. Ander kere moet die hermeneut self die skopus uit sy analise van die argumentvoering abstraheer.

Die verskillende struktuur-patrone wat in argumentatiewe tekste kan voorkom, kan soos volg grafies voorgestel word (kyk Louw 1982: 117):
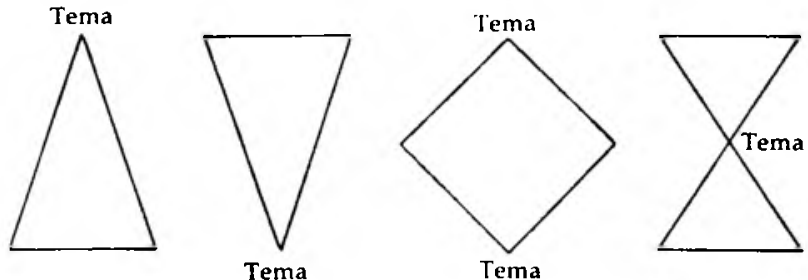
Wat die metode van eksegese van argumentatiewe diskoerse betref, kan die Suid-Afrikaanse semantiese redevoeringsanalise, saam met ander aspekte wat in die verstaan van ' $n$ teks uit die verlede in ag geneem moet word, help om die tekssegmentasie en die tekssamehang te ondersoek met die oog op die identifisering en formulering van die skopus van die diskoers. Met behulp van redevoeringsanalise word die samehang van kola en kolongroepe met ander woorde aangedui. Sodoende word die gang van die argumentvoering geanaliseer. 'n Artikel soos dié van Du Toit (1980: 119-36) oor Rom 1:18-32 kan dien as 'n goeie illustrasie van dié tipe analise. In hoofstuk 10 van sy boek, Semantics of New Testament Greek, gee Louw (1982: 117-58) in grade van ingewikkeldheid ook illustrasies van die tegniek van redevoeringsanalise.

Omdat die argumentatiewe tekste in die Nuwe Testament gewoonlik briewe is, behoort die kenmerke van die Hellenistiese brief by die ondersoek van die plek van 'n perikoop binne sy 'holistiese konteks' verdiskonteer te word. Paulus het dié briefvorm aangepas met die gevolg dat die volgende basiese elemente daarin aanduibaar is (kyk Doty 1973: 27; White 1983: 433-44): openingsgedeelte (sender, ontvanger, groet); dankseggingsgedeelte; brief-korpus (inleidingsformule: soms met eskatologiese gevolgtrekking en/of 'n aanduiding van toekomsplanne); paranese; afsluitingsgedeelte (seën- en groetformules met soms 'n vermelding van die skryfproses).

Kommunikasie van ' $n$ argumentatiewe teks vind plaas "wanneer (1) die leser se verwysingsraamwerk in ooreenstemming is met dié van die skrywer oor die berigde saak en (2) die leser dieselfde betekeniservaring het as die skrywer ten opsigte van laasgenoemde se taalgebruik wat meebring dat die leser die bedoelde boodskap kan verstaan en vertolk. Die saak moet (3) vir die leser relevant wees as gevolg waarvan sy verwysingsraamwerk ten opsigte daarvan verbreed word en (4) die kommunikasie is vir die leser aktueel wanneer die saak wat berig word vir hom relevant is" (Vorster 1977: 19; my kursivisering). Hierdie kommunikasievoorwaardes geld nie net ten opsigte van die kommunikasieverhouding skrywer-historiese leser nie, maar ook ten opsigte van dié tussen die antieke argumentatiewe teks en die hermeneut en die verhouding hermeneut-gemeente.

Wat gevolglik in hierdie kommunikasie-verhoudinge essensieel is en derhalwe op die weg van die teks na die preek metodologies verdiskonteer moet word, is: (1) dieselfde bekendheid by hermeneut 
èn gemeente met die onderwerpe en situasies wat in die verwysingsraamwerk van (historiese) skrywer en (historiese) leser met betrekking tot die berigde saak funksioneer; (2) dieselfde betekeniservaring by hermeneut èn gemeente as dié van (historiese) skrywer en (historiese) leser, met die gevolg dat die betekenisse en gebruike van Griekse woorde en uitinge beheers kan word; (3) ontleding en verstaan van die sintaktiese gang van die argument; (4) aktualiteit by hermeneut en gemeente, met die gevolg dat beide se verwysingsraamwerke ten opsigte van die berigde saak verruim of verander word.

Die volgende metodologiese stappe kan as breë raamwerk in hierdie verband dien: (1) Tekskompetensie (-beheersing); (2) Struktuuranalise en semantiese invulling; (3) Dinamiese vertaling; (4) Formulering van die skopus van die perikoop en die resessiewe temas, teen die agtergrond van die makroteks; (5) Formulering van die kommunikasie-gebeurtenis tussen die hermeneut en die teks (of temas in die teks); (6) Herstrukturering van die preek-tema in 'n preekvorm.

Met die uitdrukking 'tekskompetensie', of 'teksbeheersing', word verwys na noodsaaklike eksegetiese voorarbeid. Dit behels onder andere (1) inleidende oriëntering ten opsigte van die makroteks met behulp van inleidingswetenskappe en kommentare oor die skrywer, bronne, plek van ontstaan, historiese leser, wording en eenheid van geskrif en doel (boodskap) en teologie (motief) daarvan; (2) teksverkenning, dit wil sê 'leeskennis' van die teks met behulp van grammatikas, woordeboeke en vertalings; (3) literêre identifisering van sowel die makroteks as die mikroteks; (4) uiteensetting van die opbou van die makroteks met behulp van inleidingswetenskappe en kommentare; (5) perikoopafbakening met inagneming van die elemente van die Nuwe-Testamentiese briefvorm en met as doelstelling die identifisering van die betrokke perikoop se plek in die makroteks; (6) teksvasstelling met behulp van tekskritiek.

Die struktuuranalise en semantiese invulling kan beskou word as die analise van onderskeidelik die (sintaktiese) oppervlaktestruktuur en die (semantiese) dieptestruktuur. Eersgenoemde bestaan basies uit (1) 'n kolon-analise en (2) 'n konstituente-analise ('immediate constituent analysis'). Deur middel van die kolon-analise word (1) die onderskeie kola in die diskoers geïdentifiseer en (2) die kolainterrelasies bepaal. Die gang van die argumentvoering word sodoende gevolg. Die konstituente-analise (IC-analise) is die tegniek 
om die relasies van woorde in 'n kolon te bepaal. Die IC-analise word aangevul met ' $n$ semantiese invulling nadat die semantiese detail verkry is met behulp van 'n komponente-analise of na aanleiding van gegewens uit die semantiese woordeboek (vgl die United Bible Societies se beplande woordeboek van Nuwe-Testamentiese Grieks) of selfs uit kommentare en 'teologiese woordeboeke' (soos G Kittel se Theologische Wörterbuch zum Neuen Testament en GA Buttrick se The Interpreter's Dictionary of the Bible).

Met die eksegetiese voorarbeid, struktuuranalise en semantiese invulling agter die rug, is die hermeneut in staat om die res van die stappe op die weg van 'n argumentatiewe teks na 'n preek te voltooi.

Wat verteltekste betref: ' $n$ Vertelling is ' $n$ diskoers waarin taal georganiseer is in terme van karakters wat in 'n bepaalde struktuur van tyd en ruimte beweeg en 'n kronologiese sekwensie van episodes meebring wat in kousale verband met mekaar staan. Dié narratiewe struktuur, oftewel 'plot', kan baie simpleks of baie kompleks van aard wees. Die eksegese van verteltekste moet hierdie elemente in ag neem. Dit moet in ag neem dat 'n vertelling sy eie geslote 'vertelde wêreld' het, naamlik 'n boodskap ('ideologie') wat 'n skrywer deur middel van 'n verteller aan 'n leser kommunikeer. Die boodskap word gekommunikeer deurdat die verteller die (geïdealiseerde) leser norme vir die evaluasie verskaf. Dit wil sê, die leser word 'gemanipuleer' deur middel van die verteltegnieke waarop die verteller 'plot' konstitueer - die wyse waarop hy in kronologiese kousaliteit vertel van episodes waarin karakters binne 'n bepaalde struktuur van tyd en ruimte beweeg. Die eksegese van 'n vertelling moet as doelstelling hê die identifisering en formulering van die verteller se 'ideologiese perspektief(-we)' ('narrator's ideological point of view') wat onderliggend is aan die vertel-wyse waarop hy die vertelling struktureer ('narrative point of view').

Die metode van eksegese van verteltekste kan in verskillende rigtings opgaan. Hoe dit ook al die geval is, die analise van die verteltegnieke behoort gerig te wees op die ontrafeling van die volgende interrelasies: skrywer $\leftrightarrow$ verteller; verteller $\leftrightarrow$ implisiete leser; verteller $\leftrightarrow$ vertelde karakter; vertelde karakters in resiproke handelingsrelasies; verteller $\leftrightarrow$ verteltempus; verteller $\leftrightarrow$ vertelruimte; reële leser $\leftrightarrow$ implisiete leser (kyk verder o a Prince 1982; Van Aarde [1983] a).

Wat die kommunikasie van verteltekste betref, is die konsepte 'verwysingsraamwerk', 'betekeniservaring' en 'relevansie' waarna 
ons by die bespreking van argumentatiewe tekste verwys het, ook by die kommunikasie van verteltekste belangrik. Tog vind die kommunikasie van 'n vertelling anders plaas as dié van 'n argumentatiewe teks. Kommunikasie vind by ' $n$ vertelling in die eerste plek plaas tussen die 'verteller' en die 'geïdealiseerde leser'. Beide is literêre kategorieë in 'n 'geslote vertelde wêreld'. Die 'vertelde wêreld' verwys nie in 'n een-tot-een-verhouding na die 'werklike wêreld' nie (sonder om te sê dat daar nie raakpunte daartussen is nie). Die verteller en die geïdealiseerde leser hoef nie vooraf dieselfde verwysingsraamwerk te hê nie. Die verwysingsraamwerk word in die vertelling geskep en die geïdealiseerde leser word in die 'vertelde wêreld' ingetrek en as't ware daarin opgesluit. (E Linnemann 1975: 35 praat van 'Eindringlichkeit', oftewel 'interlocking'.) Die leser raak op hierdie wyse by die vertelde gebeure betrokke en word met die verteller se 'ideologiese perspektief(-we)' gekonfronteer.

Vanuit die gesigspunt van E Fuchs en G Ebeling se Nuwe-Hermeneutiek kan gesê word dat 'n vertelling se kommunikasie en oorredingsvermoë afhang van die literêr-estetiese geslaagdheid waarmee die verteller sy 'horison' met dié van sy gespreksgenoot laat versmelt (die sogenaamde 'Sprachereignis'/'Wortgeschehen' wat 'n 'Einverständnis' bewerkstellig). Die krag van die oorreding is met ander woorde afhanklik van die verteller se sukses om die 'wêreld' van die leser só met die 'wêreld' van die vertelling literêr te integreer, dat die assosiasie of disassosiasie wat die verteller tussen die 'ideologiese perspektiewe' van leser en vertelde karakters geskep het, eersgenoemde in die 'vertelde wêreld' intrek en opsluit sonder dat die verteller sy bedekte, manipulerende posisie ('ideologiese perspektief') in die vertelling te opsigtelik maak en daarom hierdie posisie verloor.

Hermeneuties gesien, gaan dit dus in die eksegese van 'n vertelteks om die samesmelting van die verteller se 'verstaanshorison' ('ideologiese perspektief') met dié van die hermeneut. Die hermeneut, as reële leser, word by die vertelling betrokke deurdat hy, as hy die nodige betekeniservaring besit, geassosieer word (positief of negatief) met die geïdealiseerde leser.

Die ondersoek van die geïdealiseerde leser en sy 'ideologiese perspektief(-we)' van 'n bepaalde vertelling staan in die eksegetiese proses bekend as onder andere 'funksie-analise'. Hierdie ondersoek neem in ag dat die geïdealiseerde leser van die onderskeie vertel- 
linge in die Nuwe Testament 'n historiese leser is, ingebed in 'n bepaalde temporele, politieke, godsdienstige, sosio-ekonomiese, lewensbeskoulike en kulturele bedding (kyk die vroeëre vermelde diagram). Hierdie bedding is anders as die bedding waarin die hermeneut en/of sy gemeente hom bevind. In die eksegese is dit die aangeleentheid waar gevra word na die verhouding tussen die 'vertelde wêreld' en die 'werklike wếreld', oftewel die verhouding teksreferensie (kyk Vorster 1980). Wat die vertellinge in die Nuwe-Testament betref, is dié aspek van die eksegese 'n uiters komplekse saak wat veroorsaak dat dit op meerdere wyses kommunikeer.

Wat gevolglik in die kommunikasie van 'n vertelling essensieel is en derhalwe in die eksegese met die oog op die prediking verdiskonteer moet word, is: (1) dieselfde betekeniservaring by hermeneut en gemeente as diế van skrywer-verteller en geïdealiseerde (historiese) leser, met die gevolg dat die betekenisse en gebruike van Griekse woorde en uitinge beheers kan word; (2) ontleding en verstaan van die sintaktiese verloop van die vertelling; (3) ontleding en verstaan van die 'vertelde wêreld' en die geïdealiseerde (historiese) leser, met die gevolg dat 'n 'Einverständnis' bewerkstellig word tussen verteller (via die geïdealiseerde leser) en die hermeneut.

Die volgende metodologiese stappe kan as breë raamwerk in hierdie verband dien! (1) Tekskompetensie (-beheersing); (2) Kolon-analise, konstituente-analise en dinamiese vertaling; (3) Vertellersperspektief-analise ('narrative point of view'): Ontleding van die vertelde wêreld aan die hand van die: vertelsituasie (-houding), verteltempus, vertelruimte, vertelde karakters; (4) Tematologic: die identifisering van die verteller se 'ideologiese perspektief(-we)' en dié van die hoofkarakters; (5) Funksie-analise: die ondersoek na die geïdealiseerde/implisiete leser en die verhouding tussen die 'vertelde wêreld' en die 'werklike wêreld'; (6) Formulering van die kommunikasie-gebeurtenis tussen die hermeneut en die 'ideologiese perspektief(-we)' in die teks (via dié van die geïdealiseerde leser); (7) Herstruktuering van preek-tema in 'n preek-vorm.

Die eerste stap hierbo, naamlik 'tekskompetensie', omvat dieselfde aspekte (met enkele variasies) as dit wat vroeër by die eksegetiese metode van argumentatiewe tekste bespreek is. ' $n$ Belangrike doelstelling met die tweede stap hierbo, naamlik kolon-analise, konstituente-analise en dinamiese vertaling, is om die aspek 'teksverkenning' (kyk bespreking by argumentatiewe tekste) in die eksegese van verteltekste op 'n taalwetenskaplike basis te plaas. Wat 
die metode van die analise van die 'vertelde wêreld' betref (die derde stap hierbo), is daar, soos reeds vermeld, verskeie rigtings moontlik wat deur literatuurteoretici ontwerp is. Die aspekte wat hierbo vermeld is, is ' $n$ aanpassing en verkorting van die raamwerk van analise wat deur JH Barkhuizen (1983) voorgestel word en wat gedeeltelik berus op die narratologie van Jochen Vogt (1976) (kyk Van Aarde 1983 b). Verdere navorsing en besinning in hierdie verband is egter nodig.

\section{PREEKVORM(E)?}

Wat die preekvorm(e) betref, behoort die Praktiese teoloog leiding te gee en kan die Bybelwetenskaplike begin luister en leer. Dit is interessant om op te merk dat daar dikwels in die formele homiletiek 'n verband gesien word tussen die aard van die preekvorm en die vorm en/of inhoud van die geëksegetiseerde teks. Dit lyk of die opinies in hierdie verband tussen twee moontlikhede beweeg: "Alstublief geen motto-preken! Laat de Schriftinhoud de vorm bepalen. Persoonlijk bevredigt een volgen van de tekst op de voet mij het best" (Noordegraaf 1977: 14). Bolkestein (1977 b:125) gee soos volg uitdrukking aan so 'n gedagte: "Er zijn teksten, die inzicht verschaffen en op 'kennis' gericht zijn. Zij 'informeren'. Er zijn andere teksten, die de mens aanspreken op zijn zoeken naar zin en zekerheid. $\mathrm{Zij}$ troosten of bemoedigen. Er zijn weer andere tekste, die de mens oproepen tot hendelen. $\mathrm{Zij}$ vermanen en wijzen de weg. Deze teksten moeten nie alle tot één type herleid worden. $\mathrm{Zij}$ moeten in hun verscheidenheid worden gerespecteerd." Iemand soos Stuart (1980: 75) dui 'n ander pad aan: "Do not use the exegesis outline as the sermon outline ... You must organize and incorporate the results of your exegesis into the sermon according to an order which has its primary concern to educate and challenge the congregation. It is up to you to decide what sort of a sermon, containing what elements in what order, will best convey this to the listeners ..." Oberholzer ([1970]: 136), hier te lande, huldig dieselfde opinie: "... die verbondenheid aan die saak waarom dit in die Bybel gaan, skenk aan die prediker ' $n$ bepaalde ... vryheid ... Dit laat hom vry om die vorm waarin hy die boodskap gehoor het in sy navorsing om te sit in nuwe vorme wat in hierdie tyd aanspreek, sodat daar onderrig en vermaning, vertroosting en bestraffing na die behoefte van elkeen sal plaasvind." 
Watter beginsel ook al hier behoort te geld, moet die homileet nie uit die oog verloor nie dat die vorm van sy preek deel is van die verkondiging as kommunikasie-gebeurtenis. Die volgende uitspraak van Henning Luther (1983: 277) is in hierdie verband belangrik. "Für die Rhetorik spielt die Betonung der Dialektik von Form und Inhalt eine besondere Rolle. Sie interessiert sich für die Form nicht als äusserliches Beiwerk sondern als konstitutiven Faktor, der über die Bedeutung des geäusserten Inhalts mitentscheidet ... Die hörer versucht nicht nur zu verstehen, was der Sprecher sagt, sondern warum er es sagt. Dies versucht er daran abzulesen, wie er es sagt". Hiervolgens moet die struktuur van 'n preek drie aspekte bevat: (1) ' $n$ 'informatiewe' karakter (was), (2) ' $n$ intensionele doelstelling (warum) en (3) 'n 'illokutiewe' vorm, byvoorbeeld in die vorm van 'n vraag, gebed, bevel, wens ensovoorts (wie). Aldrie aspekte is in die struktuur van die preek geïntegreerd met mekaar verbind en is vir effektiewe kommunikasie onontbeerlik.

Deur middel van die verkondiging as 'n kommunikasie-gebeurtenis, omdat bogenoemde drie aspekte gestruktureerd daarin voorkom, behoort die gemeentelid uit die 'informasie' wat hy op 'n intensionele wyse in 'n geslaagde vorm verneem het, die teks herken en God se Woord erken. Eers dan het 'explicatio' sonder probleme 'applicatio' geword.

\section{Literatuurverwysings}

ANDEREGG, J 1973. Fiktion und Kommunikation. Göttingen: Vandenhoeck \& Ruprecht.

BARKHUIZEN, JH 1983. Raamwerk vir analise. (Ongepubliseerde diktaat, Departement Grieks, Universiteit van Pretoria).

BEST, E 1978. From text to sermon. Responsible use of the New Testament in preaching. Atlanta: John Knox.

BOLKESTEIN, MH 1977 a. Homiletische Oogst 1975, in Beek, MA et al 1977. Postille 1976-1977. 's-Gravenhage: Boekencentrum, 226-33.

BOLKESTEIN, MH 1977 b: Zo wordi er gepreekt. Verslag van een onderzoek naar de communicatievormen in 89 preken. Den Haag: Boekencentrum.

BROOKS, C \& RP WARREN 1970. Modern rhetoric. 3rd Edition. New York: Harcourt.

BULTMANN, R 1964. How does God speak to us through the Bible? in Existence and faith. Shorter writings of Rudolf Bultmann. (Selected, translated and introduced by SM Ogden.) London: Collins Clear-Type Press, 196-201.

DEIST, FE \& J BURDEN 1980. ' $n$ ABC van Bybeluitleg. Pretoria: Van Schaik.

DE KLERK, JJ 1972. Die preekvorm, in Marais, BJ \& CWH Boshoff (red) 1972. Rondom die prediking. (Erebundel aangebied aan prof HDA du Toit.) Pretoria: NG Kerkboekhandel, 62-76.

DE KLERK, JJ 1979. Die nood aan aktuele prediking, in De Klerk, JJ et al 1979. Aktuele prediking Pretoria: NG Kerkboekhandel, 1-27. 
DOTY, WG 1973. Letters in primitive Christianity. Philadelphia: Fortress.

DU TOIT, AB 1980. Die praktyk van die eksegese in die lig van nuwere wetenskaplike ontwikkeling, in Die Nuwe-Testamentiese Wetenskap vandag. Departemente Nuwe Testament (A \& B) en Grieks, Universiteit van Pretoria, 119-36.

EBELING, G 1959. Wort Gottes und Hermeneutik. ZThK 56, 224-51.

FENDT, L 1970. Homiletik. 2. Auflage. (Neu bearbeitet von B Klaus.) Berlin: De Gruyter.

JONKER, H s a. Actuele prediking. Tweede druk. Nijkerk: GF Callenbach NV.

LINNEMAN, E 1975. Die Gleichnisse Jesu. Einführung und Auslegung. 6. Auflage. Göttingen: Vandenhoeck \& Ruprecht.

LOUW, JP 1982. Semantics of New Testament Greek. Philadelphia: Fortress.

LUTHER, H 1983. Predigt als Handlung. Überlegungen zur Pragmatik des Predigens. ZThK 80, 223-43.

MARXSEN, W 1968. Der Beitrag der wissenschaftlichen Exegese des Neuen Testanment für die Verkūndigung, in Der Exeget als Theologe. Vorträge zum Neuen Testament. Gūtersloh: Gütersloher Verlagshaus Gerd Mohn, 52-74.

NIDA, EA 1981. Signs. Sense. Translation. Departement Grieks, Universiteit van Pretoria. (Ongepubliseerde seminaar-referate).

NOORDEGRAAF, A 1977. Wezen en functie van de prediking, in Beek, MA et al. 1977. Postille 1976-1977. 's-Gravenhage: Boekencentrum, 7-15.

OBERHOL.ZER JP [1970]. Eksegese en prediking. HTS 30/3 \& 4, 129-37.

PIETERSE, HJC 1979 a. Skrifverstaan en prediking. Die verhouding van woordgebeure en verstaansgebeure by Gerhard Ebeling as antwoord op die nood van die prediking. Pretoria: NG Kerkboekhandel.

PIETERSE, HJC 1979 b. Meditations on God's Word for today. Pretoria. DR Church Booksellers.

PRINCE, G 1982. Narratology. The form and function of narrative. Berlin: Mouton.

RALPH, MN 1980. New biblical criticism and the synoptic gospels. (PH.D dissertation, University of Kentucky). Ann Arbor: University Microfilms International.

SEUNG, TK 1982. Semiotics and thematics in hermeneutics. New York: Columbia University Press.

STUART, D 1980. Old Testament exegesis. A primer for students and pastors. Philadelphia: Westminister.

THOMPSON, WD 1981.Preaching biblically. Exegesis and interpretation. Nashville: Abingdon.

VAN AARDE, AG [1983] a. Die vertellerperspektief-analise. 'n Literatuurteoretiese benadering in die eksegese van die evangelies. HTS 38/4, 58-82.

VAN AARDE, AG 1983 b. Eksegese van vertelmateriaal. (Ongepubliseerde seminaarreferaat, Universiteit van Pretoria).

VOGT, J 1976. Aspekte erzählender Prosa. 2. Auflage. Opladen: Westdeutscher Verlag.

VORSTER, WS 1977. 'n Ou Boek in 'n nuwe wêreld. Gedagtes rondom die interpretasie van die Nuwe Testament. Pretoria: Universiteit van Suid-Afrika.

VORSTER, WS 1980. Die tekssoort evangelie en verwysing. Theologica Evangelica 13, 27-48.

VORSTER, WS 1983 a. Implikasies van die onderskeiding tussen fiktiewe en saaktekste ten opsigte van die interpretasie van die Nuwe Testament. Ongepubliseerde seminaar-voordrag 24 Mei 1983, Departement Nuwe-Testamentiese Wetenskap (Afdeling A), Universiteit van Pretoria.

VORSTER, WS 1983 b. 1 Enoch and the Jewish literary setting of the New Testament. A study in text types. Ongepubliseerde voordrag NTWSA Julie 1983. (Vir publikasie in Neotestamentica 17).

WATSON, NM 1981. Exegesis - Marxsen's contribution. ABR 29, 10-15.

WHITE, JL 1983. Saint Paul and the apostolic letter tradition. CBQ 45, 433-44. 